\title{
PENGARUH KINERJA KEUANGAN TERHADAP HARGA SAHAM PADA BANK UMUM MILIK PEMERINTAH
}

\author{
Ida Ayu Agung Idawati ${ }^{(1)}$ \\ I Gede Surya Pratama ${ }^{(2)}$ \\ IA Cynthia Saisaria Mandasari ${ }^{(3)}$ \\ ${ }^{(1)(2)(3)}$ Fakultas Ekonomi, Universitas Warmadewa, Bali, Indonesia \\ e-mail: dayuagung84@gmail.com
}

\begin{abstract}
One of the considerations of investors in investing in shares is fluctuations in stock prices. Stock prices are one indicator of the success of company management. Investor or prospective investor trust is very beneficial for the issuer, because the more people who trust the issuer, the stronger the desire to invest in the issuer. The purpose of this study was to determine the financial performance as measured by the variable Capital Adequacy Ratio (CAR), Net Profit Margin (NPM), Loan to Deposit Ratio (LDR) and Return On Equity (ROE) to the stock prices of government-owned commercial banks on the IDX.

The technical analysis used in this study is multiple linear regression and $t$ (t-test) for partial analysis. Based on the results of multiple linear regression analysis, the regression equation $Y=18.905+0.149(X 1)+0.393(X 2)-0.487$ $(X 3)+0.238(X 4)$ is obtained. T-test testing from the regression results obtained that the Capital Adequacy Ratio and Return On Equity partially did not have a significant effect on stock prices. While the Net Profit Margin and Loan to Deposit Ratio partially have a significant effect on stock prices.
\end{abstract}

Keyword: Capital adequacy ratio, net profit margin, loan to deposit ratio, Return On Equity Ratio, Stock Price

\section{PENDAHULUAN}

Investasi merupakan suatu hal yang sudah mulai dikenal oleh berbagai kalangan masyarakat di Indonesia. Masyarakat Indonesia melakukan investasi di berbagai bidang, misalkan emas, tanah, properti dan lain sebagainya. Selain itu, salah satu tempat investasi yang dapat digunakan oleh investor adalah pasar 
modal. Pasar modal merupakan tempat bagi investor yang ingin menyalurkan dana yang dimilikinya dalam bentuk saham. Saham merupakan sertifikat yang menunjukkan kepemilikan (Hartono, 2014: 586). Apabila berinvestasi dalam bentuk saham, secara periodik investor akan memperoleh keuntungan dalam bentuk capital gain atau dividen. Perolehan keuntungan tersebut yang memotivasi investor untuk berinvestasi saham.

Selain keuntungan tentu ada hal-hal yang perlu dipertimbangkan dalam pengambilan keputusan untuk berinvestasi saham. Salah satunya adalah fluktuasi harga saham yang tidak menentu dan mengandung risiko yang menyebabkan ketidakpastian investor. Risiko ini bisa menurunkan tingkat kepercayaan investor dalam berinvestasi sehingga dapat mempengaruhi kinerja pasar modal dan pada akhirnya akan mempengaruhi harga saham (Priatinah, 2012).

Harga saham merupakan salah satu indikator keberhasilan pengelolaan perusahaan. Apabila harga saham suatu perusahaan selalu mengalami kenaikan, maka investor atau calon investor menilai bahwa perusahaan berhasil dalam mengelola usahanya. Kepercayaan investor atau calon investor sangat bermanfaat bagi emiten, karena semakin banyak orang yang percaya terhadap emiten maka keinginan untuk berinvestasi pada emiten semakin kuat. Semakin banyak permintaan terhadap saham suatu emiten maka dapat menaikkan harga saham tersebut. Jika harga saham yang tinggi dapat dipertahankan maka kepercayaan investor atau calon investor terhadap emiten juga semakin tinggi dan hal ini dapat menaikkan nilai 
emiten. Sebaliknya, jika harga saham mengalami penurunan terus-menerus berarti dapat menurunkan nilai emiten dimata investor atau calon investor (Patar, 2014).

Melihat pentingnya harga saham, maka investor perlu menganalisis faktorfaktor apa saja yang mempengaruhi pergerakan dalam meneliti harga saham yang akan dibeli oleh investor. Adapun faktor yang mempengaruhi pergerakan harga saham yaitu faktor eksternal dan faktor internal. Faktor eksternal adalah faktor yang berada di luar perusahaan, tetapi mempunyai pengaruh terhadap kenaikan atau penurunan kinerja perusahaan baik secara langsung maupun tidak langsung. Adapun faktor eksternal tersebut yaitu tingkat inflasi, keadaan resesi ekonomi negara, perkembangan kurs, dan keadaan politik suatu negara.

Selain itu faktor internal adalah faktor yang berasal dari dalam perusahaan yang dapat dikendalikan oleh manajemen perusahaan, yang termasuk faktor internal yaitu analisis laporan keuangan perusahaan. Melalui analisis laporan keuangan ini dapat diketahui kekuatan serta kelemahan yang dimiliki perusahaan. Salah satu alternatif untuk mengetahui apakah informasi keuangan yang dihasilkan dapat bermanfaat untuk memproduksi harga saham di pasar modal, termasuk kondisi keuangan perusahaan di masa depan adalah dengan melakukan analisis kinerja keuangan.

Perbankan merupakan salah satu lembaga keuangan yang mempunyai peran strategis dalam menyelaraskan, menyerasikan, serta menyeimbangkan berbagai unsur pembangunan. Peran yang strategis tersebut terutama disebabkan oleh fungsi utama bank sebagai suatu lembaga yang dapat menghimpun dan menyalurkan dana masyarakat secara efektif dan efisien, yang dengan berdasarkan 
asas demokrasi ekonomi mendukung pelaksanaan pembangunan dalam rangka meningkatkan pemerataan dan hasil-hasilnya, pertumbuhan ekonomi dan stabilitas nasional, kearah peningkatan taraf hidup rakyat banyak.

Menurut Undang-Undang Republik Indonesia No. 10 Tahun 1998 tanggal 10 November 1998 tentang perbankan, yang dimaksud dengan Bank adalah badan usaha yang menghimpun dana dari masyarakat dalam bentuk simpanan dan mengeluarkannya kepada masyarakat dalam bentuk kredit dan atau bentuk-bentuk lainnya dalam rangka meningkatkan taraf hidup rakyat banyak (Kasmir, 2014: 24). Sedangkan perbankan merupakan segala sesuatu yang menyangkut tentang bank, mencangkup kelembagaan, kegiatan usaha, serta cara proses dalam melaksanakan kegiatan usahanya (Sanjaya, 2014).

Kinerja keuangan adalah gambaran dari pencapaian keberhasilan perusahaan dapat diartikan sebagai hasil yang telah dicapai atas berbagai aktivitas yang telah dilakukan. Kinerja keuangan adalah suatu analisis yang dilakukan untuk melihat sejauh mana suatu perusahaan telah melaksanakan dengan menggunakan aturan-aturan pelaksanaan keuangan secara baik dan benar. Penilaian kondisi dan kinerja keuangan perusahaan dapat menggunakan rasio yang merupakan perbandingan angka-angka yang terdapat pada pos-pos laporan keuangan (Fahmi, 2013 :50). Hasil penelitian yang dilakukan Ulfa (2014) menunjukkan bahwa kinerja keuangan yang diproksikan oleh LDR, ROA, dan CAR secara parsial tidak berpengaruh signifikan terhadap harga saham pada Bank Umum Milik Pemerintah yang go public di Bursa Efek Indonesia (BEI). Ardhila (2016) menunjukkan hasil penelitian bahwa variabel yang terdiri dari LDR, NPM 
dan DER secara parsial tidak berpengaruh signifikan terhadap harga saham terdaftar di Bursa Efek Indonesia. Hasil penelitian tersebut berbeda dengan hasil penelitian dari Pertiwi (2017) yang menunjukkan bahwa kinerja keuangan perusahaan dalam rasio berdasarkan uji parsial (t-test) EPS berpengaruh signifikan terhadap harga saham.

Laporan Perekonomian Indonesia 2012 menunjukkan kinerja pasar saham domestik menjadi positif akibat dukungan struktur fundamental dan sektoral yang semakin baik. Dari sisi fundamental, pertumbuhan laba bersih perusahaan yang mencapai sebelas persen pada tahun 2012 menjadi faktor positif penggerak indeks harga saham gabungan (IHSG) dan saham-saham dari sektor keuangan masih dominan dalam pembentukan (IHSG). Hal tersebut mencerminkan bahwa kinerja perusahaan sangat berpengaruh terhadap harga saham baik secara individu maupun gabungan (Sanjaya, 2014:7).

Kinerja perbankan dapat diukur dengan menggunakan beberapa indikator yaitu permodalan yang diukur dengan Capital Adequacy Ratio (CAR), kemampuan perusahaan menghasilkan laba bersih yang diukur dengan Net Profit Margin (NPM), likuiditas yang dapat diukur dengan Loan to Deposit Ratio (LDR), dan rentabilitas yang dapat diukur dengan ratio Return On Equity (ROE).

Penelitian ini bertujuan untuk mengetahui kinerja keuangan yang diukur dengan variabel Capital Adequacy Ratio (CAR), Net Profit Margin (NPM), Loan to Deposit Ratio (LDR) dan Return On Equity (ROE) terhadap harga saham bank umum milik pemerintah di BEI. 


\section{Harga Saham}

Harga saham adalah nilai suatu saham yang mencerminkan kekayaan perusahaan yang mengeluarkan saham tersebut, dimana perubahan atau fluktuasinya sangat ditentukan oleh kekuatan permintaan dan penawaran yang terjadi di pasar bursa (pasar sekunder). Semakin banyak investor yang ingin membeli atau menyimpan saham, harganya semakin naik. Sebaliknya semakin banyak investor yang ingin menjual atau melepaskan suatu saham, maka harganya semakin bergerak turun. (Setiawan,2009) dalam (Lasmi,2017:23).

\section{Kinerja Keuangan}

Kinerja merupakan hasil dari evaluasi terhadap pekerjaan yang telah selesai dilakukan, hasil pekerjaan tersebut dibandingkan dengan kriteria yang telah ditetapkan bersama. Setiap pekerjaan yang telah selesai dilakukan perlu dilakukan penilaian atau pengukuran secara periodik (Sujarweni, 2017:71).

Tujuan Penilaian Kinerja Keuangan:

a Untuk mengetahui tingkat likuiditas, yaitu kemampuan perusahaan untuk memperoleh kewajiban keuangannya yang harus segera dipenuhi atau kemampuan perusahaan untuk memenuhi keuangannya pada saat ditagih.

b Untuk mengetahui tingkat solvabilitas, yaitu kemampuan perusahaan untuk memenuhi kewajiban keuangannya apabila perusahaan tersebut dilikuidasi baik kewajiban keuangan jangka pendek maupun jangka panjang.

c Untuk mengetahui tingkat rentabilitas atau profitabilitas, yaitu menunjukkan kemampuan perusahaan untuk menghasilkan laba selama periode tertentu. 
d Untuk mengetahui tingkat stabilitas usaha, yaitu kemampuan perusahaan untuk melakukan usahanya dengan stabil, yang diukur dengan mempertimbangkan kemampuan perusahaan untuk membayar beban bunga atas hutang-hutangnya termasuk membayar kembali pokok hutangnya tepat pada waktunya serta kemampuan membayar deviden secara teratur kepada para pemegang saham tanpa mengalami hambatan atau krisis keuangan.

\section{Rasio Keuangan}

Rasio keuangan adalah suatu kajian yang melihat perbandingan antara jumlah-jumlah yang terdapat pada laporan keuangan dengan mempergunakan formula-formula yang dianggap representative untuk diterapkan. Rasio keuangan ini sangat penting gunanya untuk melakukan analisa terhadap kondisi keuangan perusahaan. Fahmi, (2013:49)

\section{Hipotesis}

\section{Pengaruh CAR (Capital Adequacy Ratio) Terhadap Harga Saham}

Capital Adequacy Ratio (CAR) menunjukkan sejauhmana modal pemilik saham dapat menutupi aktiva berisiko. Haryetti (2012) menyatakan bahwa Capital Adequacy Ratio (CAR) berpengaruh signifikan terhadap harga saham pada perusahaan perbankan yang go publik di BEI.

$\mathrm{H}_{1}$ : Capital Adequacy Ratioberpengaruh signifikan terhadap harga saham Bank Umum Milik Pemerintah Tahun 2011-2016

\section{Pengaruh NPM (Net Profit Margin) Terhadap Harga Saham}

Net Profit Margin (NPM) merupakan perbandingan antara laba bersih setelah pajak dengan penjualan. Penelitian dari Leni (2012) Net Profit Margin (NPM) mempunyai pengaruh positif terhadap harga saham pada perusahaan jasa 
Transportasi Yang Go Public di PT. Bursa Efek Indonesia Tahun 2006-2010. Evayani (2012) menemukan bahwa terdapat pengaruh Net Profit Margin (NPM) berpengaruh positif terhadap harga saham pada perusahaan jasa Transportasi yang go public di PT. Bursa Efek Indonesia Tahun 2006-2010. Ulfa (2014) Net Profit Margin (NPM) mempunyai pengaruh positif terhadap harga saham pada perusahaan Bank Umum Milik Pemerintah.

$\mathrm{H}_{2}$ : Net Profit Margin berpengaruh signifikan terhadap harga saham Bank Umum Milik Pemerintah yang Terdaftar di Bursa Efek Inodensia Tahun 2011-2016

\section{Pengaruh LDR (Loan to Deposit Ratio) Terhadap Harga Saham}

LDR (Loan to Deposit Ratio) merupakan salah satu rasio keuangan yang mengukur likuiditas perusahaan. Rasio ini dimaksudkan untuk mengukur seberapa besar pendanaan pinjaman yang diberikan oleh bank yang bersumber dari dana pihak ketika (Winarsa, 2010) dalam (Setiawati, 2015). Meningkatnya LDR rasio berarti meningkat pula pendapatan bunga yang diperoleh oleh bank. Setiawati (2015) yang menunjukkan bahwa kinerja keuangan yang diproksikan oleh LDR berpengaruh positif dan signifikan terhadap harga saham perbankan yang terdaftar di Bursa Efek Indonesia Tahun 2011-2013.

$\mathrm{H}_{3}$ :Loan to Deposit Ratio berpengaruh signifikan terhadap harga saham Bank Umum Milik Pemerintah yang terdaftar di Bursa Efek Indonesia Tahun 20112016

\section{Pengaruh ROE (Return On Equity ) terhadap Harga Saham}

ROE (Return On Equity) menunjukkan penghasilan yang tersedia bagi pemilik perusahaan atas dasar modal yang mereka investasikan dalam peusahaan. Leni (2012) menemukan bahwa Return On Equity (ROE) yang berpengaruh positif terhadap harga saham pada perusahaan jasa Transportasi yang go public di 
PT. Bursa Efek Indonesia Periode 2006-2010. Evayani (2012) diketahui bahwa Return On Equity (ROE) berpengaruh positif terhdap harga saham pada perusahaan jasa Transportasi yang go public di PT. Bursa Efek Indonesia Tahun 2006-2010. Satria dan Haryani (2015) Return On Equity (ROE) berpengaruh positif dan signifikan terhadap harga saham 10 Bank Terkemuka di Indonesia.

$\mathrm{H}_{4}$ : Return on Equity berpengaruh signifikan terhadap harga saham Bank Umum Milik Pemerintah Tahun 2011-2016

Penelitian ini diharapkan mampu memberikan gambaran mengenai pengaruh kinerja keuangan terhadap harga saham. Perusahaan dalam hal ini bank umum milik pemerintah bisa memanfaatkan hasil penelitian ini untuk tindak lanjut kinerja keuangannya di tahun-tahun berikutnya.

\section{METODE PENELITIAN}

Penelitian ini adalah penelitian deskriptif kuantitatif. Penelitian deskriptif kuantitatif yaitu penelitian yang mengungkap besar atau kecilnya suatu pengaruh atau hubungan antar variabel yang dinyatakan dalam angka-angka, dengan cara mengumpulkan data-data yang merupakan faktor pendukung terhadap pengaruh antara variabel-variabel yang bersangkutan kemudian mencoba untuk dianalisis.

Ditinjau dari sumber datanya, penelitian ini menggunakan sumber data sekunder (secondary data) dimana sumber data penelitiannya diperoleh peneliti secara tidak langsung melalui media perantara (diperoleh dan dicatat oleh pihak lain).

Populasi dalam penelitian ini adalah bank umum milik pemerintah yang listing di Bursa Efek Indonesia selama Tahun 2011-2016. Metode penentuan sampel menggunakan metode purposive sampling, yaitu pengambilan sampel dengan kriteria. Kriteria penentuan sampelnya adalah Bank Umum Milik 
Pemerintah yang memiliki laporan keuangan lengkap yaitu tahun 2011 sampai dengan 2016 dan memiliki rasio keuangan yang lengkap. Berdasarkan kriteria tersebut, diperoleh sampel sebanyak 4 bank, yaitu:

Tabel 1 Sampel Penelitian

\begin{tabular}{rllc}
\hline No & Kode & \multicolumn{1}{c}{ Nama Perusahaan } & $\begin{array}{c}\text { Tanggal Listing } \\
\text { Pertama kali }\end{array}$ \\
\hline 1 & BBNI & Bank Negara Indonesia (Persero) Tbk & 25 November 1996 \\
2 & BBRI & Bank Rakyat Indonesia (Persero) Tbk & 10 November 2003 \\
3 & BBTN & Bank Tabungan Negara (Persero) Tbk & 17 Desember 2019 \\
4 & BMRI & Bank Mandiri (Persero) Tbk & 14 Juli 2003 \\
\hline
\end{tabular}
Sumber: IDX

Teknik pengumpulan data yang digunakan dalam penelitian ini adalah studi dokumentasi, yaitu mengumpulkan data dengan cara mencatat dari dokumen-dokumen yang ada dari lembaga atau perusahaan. Data penelitian ini diperoleh dari Bursa Efek Indonesia (BEI) melalui situs www.idx.co.id.

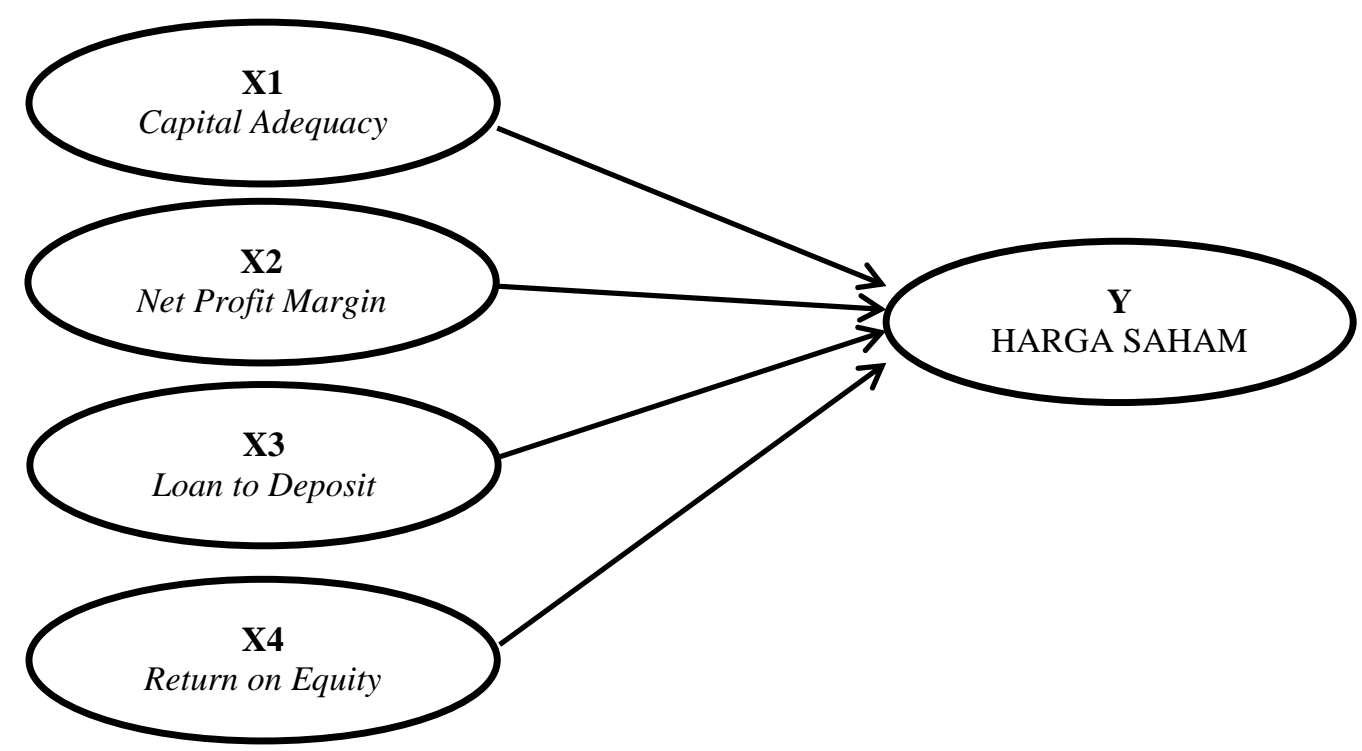

Gambar 1 Kerangka PenelitianPenelitian 


\section{HASIL PENELITIAN DAN PEMBAHASAN}

Hasil Uji normalitas menunjukkan bahwa nilai Asymp.Sig. (2-tailed) sebesar 0.944 lebih besar dari 0,05. Berarti seluruh data terdistribusi normal. Hasil uji multikolinearitas dilihat dari nilai Tolerance dan VIF. Berikut adalah tabel hasil uji multikolinearitas.

\section{Tabel 2 Hasil Uji Multikolinearitas}

\begin{tabular}{ccc}
\hline Variabel & Tolerance & VIF \\
\hline X1 & 0.866 & 1.154 \\
X2 & 0.902 & 1.108 \\
X3 & 0.936 & 1.069 \\
X4 & 0.838 & 1.194
\end{tabular}

Sumber: data diolah, 2018

Berdasarkan tabel diatas, semua variabel memiliki nilai Tolerance lebih dari 0.10 dan VIF kurang dari 10. Hasil ini menunjukkan bahwa di dalam model regresi tidak terjadi multikolinearitas antar variabel.

Hasil uji autokorelasi menunjukkan bahwa nilai Durbin Watson adalah sebesar 1,867. Nilai $d_{u}=1,7753$ lebih kecil dari nilai Durbin Watson $(1,867)$, dan nilai Durbin Watson $(1,867)$ lebih kecil dari nilai $4-\mathrm{d}_{\mathrm{u}}$ sebesar 2,2247.

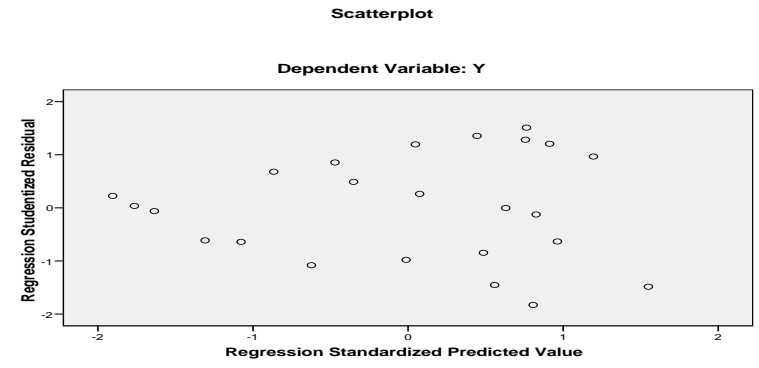

Gambar 2 Hasil Uji heteroskedastisitas Sumber: Data diolah 
Berdasarkan gambar 1 yaitu grafik scatterplots diatas terlihat titik-titik yang ada membentuk pola tertentu yang teratur (bergelombang, melebar kemudian menyempit). Hal ini dapat disimpulkan bahwa terjadi heterokedastisitas pada model regresi sehingga model regresi tidak layak untuk digunakan.

Hasil persamaan regresi linier berganda dalam penelitian ini adalah sebagai berikut:

$$
\begin{aligned}
& Y=\alpha+b_{1} X_{1}+b_{2} X_{2}+b_{3} X_{3}+b_{4} X_{4} \\
& Y=182.905+0.149\left(X_{1}\right)+0.393\left(X_{2}\right)-0.487\left(X_{3}\right)+0.238\left(X_{4}\right)
\end{aligned}
$$

Keterangan:

$$
\begin{array}{ll}
\mathrm{Y} & =\text { Harga Saham } \\
\alpha & =\text { Konstanta } \\
\mathrm{X}_{1} & =\text { Capital Adequacy Ratio (CAR) } \\
\mathrm{X}_{2} & =\text { Net Profit Margin (NPM) } \\
\mathrm{X}_{3} & =\text { Loan to Deposit Ratio (LDR) } \\
\mathrm{X}_{4} & =\text { Return on Equity Ratio (ROE) }
\end{array}
$$

Persamaan regresi di atas dapat diuraikan sebagai berikut:

$\alpha \quad=182.905$ (Konstanta)

Ketika Capital Adequacy Ratio $\left(\mathrm{X}_{1}\right)$, Net Profit Margin $\left(\mathrm{X}_{2}\right)$, Loan to Deposit Ratio $\left(\mathrm{X}_{3}\right)$, Return on Equaty Ratio $\left(\mathrm{X}_{4}\right)$, konstan atau 0 maka Y (Harga Saham) memiliki nilai sebesar $182.905 \%$.

$\mathrm{b}_{1}=0.149\left(\right.$ Koefisien Regresi $\left.\mathrm{X}_{1}\right)$ menjelaskan;

Jika variabel Capital Adequacy Ratio $\left(\mathrm{X}_{1}\right)$ bertambah $1 \%$ maka berdampak pada Y (Harga Saham) akan mengalami peningkatan sebesar $0.149 \%$. 
$\mathrm{b}_{2} \quad=0.393\left(\right.$ Koefisien Regresi $\mathrm{X}_{2}$ ) menjelaskan;

Jika variabel Net Profit Margin $\left(\mathrm{X}_{2}\right)$ bertambah bertambah $1 \%$ maka Y (Harga Saham) akan mengalami peningkatan sebesar $0.393 \%$.

$b_{3}=-0.487$ (Koefisien Regresi $X_{3}$ ) menjelaskan;

Jika variabel Loan to Deposit Ratio $\left(\mathrm{X}_{3}\right)$ bertambah $1 \%$ maka Y (Harga Saham) akan mengalami penurunan sebesar $-0.487 \%$.

$\mathrm{b}_{4} \quad=0.238\left(\right.$ Koefisien Regresi $\left.\mathrm{X}_{4}\right)$ menjelaskan;

Jika Return On Equity Ratio $\left(\mathrm{X}_{4}\right)$ bertambah $1 \%$ maka Y (harga Saham) akan mengalami peningkatan sebesar $0.238 \%$.

Persamaan analisis regresi linier berganda diatas menunjukkan arah pengaruh dari masing-masing variabel bebas terhadap variabel terikat yang ditunjukkan oleh koefisien regresi masing-masing variabel bebasnya. Koefisien variabel bebas yang bertanda positif berarti bahwa variabel tersebut memiliki pengaruh yang searah terhadap harga saham, sedangkan variabel bebas yang bertanda negatif memiliki pengaruh yang berlawanan terhadap harga saham.

\section{a. Pengaruh Capital Adequacy Ratio (X1) terhadap harga saham (Y)}

Nilai signifikansi Capital Adequacy Ratio (X1) sebesar 0,362 lebih besar dari $\alpha=0,05$ atau 5\%, ini berarti bahwa Capital Adequacy Ratio (X1) tidak berpengaruh signifikan terhadap harga saham Bank Umum Milik Pemerintah yang terdaftar di Bursa Efek Indonesia tahun 2011-2016. Nilai thitung sebesar 0.933 lebih kecil dari $t_{\text {tabel }}$ sebesar 2,093 $(0,025 ; 19)$, maka $t_{\text {hitung }}$ berada pada daerah penerimaan Ho. Ini berarti Capital Adequacy Ratio (X1) tidak berpengaruh terhadap harga saham (Y). 


\section{b. Net Profit Margin (X2) terhadap harga saham (Y)}

Nilai signifikansi Net Profit Margin (X2) sebesar 0,021 lebih kecil dari $\alpha=0,05$ atau $5 \%$, ini berarti bahwa Net Profit Margin (X2) secara parsial berpengaruh signifikan terhadap harga saham Bank Umum Milik Pemerintah yang terdaftar di Bursa Efek Indonesia tahun 2011-2016 dengan menganggap variabel lain adalah konstan. Nilai $t_{\text {hitung }}$ sebesar 2,509 lebih besar dari $t_{\text {tabel }}$ sebesar 2,093 $(0,025 ; 19)$, maka $t_{\text {hitung }}$ berada pada daerah penolakan Ho. Ini berarti Net Profit Margin (X2) secara parsial berpengaruh signifikan terhadap harga saham (Y)

\section{c. Pengaruh Loan to Deposit Ratio (X3) terhadap harga saham (Y)}

Nilai signifikansi Loan to Deposit Ratio (X3) sebesar 0.005 lebih kecil dari $\alpha=0,05$ atau $5 \%$, ini berarti bahwa Loan to Deposit Ratio (X3) secara parsial berpengaruh signifikan terhadap harga saham Bank Umum Milik Pemerintah yang terdaftar di Bursa Efek Indonesia tahun 2011-2016 dengan menganggap variabel lain adalah konstan. Nilai $t_{\text {hitung }}$ sebesar -3.165 lebih kecil dari $t_{\text {tabel }}$ sebesar 2,093 $(0,025 ; 19)$, maka $t_{\text {hitung }}$ berada pada daerah penolakan Ho. Ini berarti Loan to Deposit Ratio (X3) secara parsial berpengaruh terhadap harga saham (Y).

\section{d. Pengaruh Return on Equity Ratio (X4) terhadap harga saham (Y)}

Nilai signifikansi Return on Equity Ratio (X4) sebesar 0.160 lebih besar dari $\alpha=0,05$ atau 5\%, ini berarti bahwa Return on Equity Ratio (X4) tidak berpengaruh signifikan terhadap harga saham Bank Umum Milik Pemerintah yang terdaftar di Bursa Efek Indonesia tahun 2011-2016 dengan menganggap variabel lain adalah konstan. Nilai $t_{\text {hitung }}$ sebesar 1,463 lebih kecil dari $t_{\text {tabel }}$ sebesar 2,093 
$(0,025 ; 19)$, maka $t_{\text {hitung }}$ berada pada daerah penerimaan H0. Ini berarti Return On Equity (X4) secara parsial tidak berpengaruh signifikan terhadap harga saham (Y).

\section{SIMPULAN}

1. Capital Adequacy Ratio (CAR) tidak berpengaruh signifikan terhadap harga saham Bank Umum Milik Pemerintah yang terdaftar di Bursa efek Indonesia Tahun 2011-2016.

2. Net Profit Margin (NPM) secara parsial berpengaruh signifikan terhadap harga saham Bank Umum Milik Pemerintah yang terdaftar di Bursa Efek Indonesia Tahun 2011-2016.

3. Loan to Deposit Ratio (LDR) secara parsial berpengaruh signifikan terhadap harga saham Bank Umum Milik Pemerintah yang terdaftar di Bursa Efek Indonesia Tahun 2011-2016.

4. Return on Equity Ratio (ROE) tidak berpengaruh signifikan terhadap harga saham Bank Umum Milik Pemerintah yang terdaftar di Bursa efek Indonesia Tahun 2011-2016.

Fluktuasi harga saham suatu perusahaan atau bank akan mempengaruhi nilai perusahaan atau bank yang bersangkutan. Peningkatan dan penurunan nilai perusahaan bisa dikatakan akibat dari minat investor untuk berinvestasi dalam perusahaan tersebut. Penelitian ini menunjukkan bahwa rasio CAR (Capital Adequacy Ratio) dan ROE (Return on equity) tidak berpengaruh signifikan terhadap harga saham bank. Berdasarkan hasil tersebut, perusahaan perlu memperhatikan kinerja keuangan dalam hal ini diukur dengan rasio-rasio keuangan yang mempengaruhi harga saham dan yang tidak mempengaruhi harga 
saham. Kinerja keuangan adalah sebagai salah satu faktor penilaian pencapaian nilai perusahaan.

Hasil penelitian ini akan memberikan masukan bagi:

1. Investor, sebagai pertimbangan awal untuk melakukan investasi di bank umum yang terdaftar di BEI.

2. Manajemen, sebagai motivasi untuk meningkatkan kinerja internal bank sehingga bisa meningkatkan nilai bank yang bersangkutan.

3. Pengambil keputusan, sebagai bahan pertimbangan untuk pengambilan keputusan terkait kinerja bank di masa yang akan datang.

\section{KETERBATASAN PENELITIAN}

1. Penilaian Kinerja suatu perusahaan harus dilakukan terus menerus, tidak hanya dalam beberapa periode. Penelitian ini hanya menganalisis kinerja selama 5 periode saja (2011-2016).

2. Rasio keuangan yang digunakan hanya beberapa saja.

3. Jumlah penelitian sebelumnya yang digunakan sebagai acuan masih kurang.

\section{DAFTAR PUSTAKA}

Abdulah, F. 2013. Dasar-Dasar Manajemen Keuangan. Malang:Universitas Muhammadiyah Malang.

Ardhila, F.H dan Utiyati, S. 2016. Pengaruh Kinerja Keuangan Terhadap Harga Saham Perusahaan Property yang Terdaftar di BEI. Jurnal Riset dan Ilmu Manajemen. 5 (1):1-18

Darmadji, T.H.M. 2012. Pasar Modal di Indonesia Pendekatan Tanya Jawab. Jakarta: Salemba Empat.

Darmawi, H. 2014. Manajemen Perbankan. Jakarta:Bumi Aksara.

Sanjaya, M.D. 2014. Pengaruh Kinerja Keuangan Terhadap Harga Saham Perbankan Yang Listing Di Bursa Efek Indonesia (BEI). Skripsi tidak dipublikasikan.

Fahmi, I. 2013. Pengantar Manajemen Keuangan. Bandung:Alfabeta.

Ghozali, Imam.2013.Aplikasi Analisis Multivariate dengan Program SPSS. Cetakan Keempat.Semarang:Badan Penerbit Universitas Diponegoro. 
Hartono, Jogiyanto. (2014), Teori Portofolio dan Analisis Investasi, ed 9. Yogyakarta: BPFE

Kasmir. 2014. Analisis Laporan Keuangan. Jakarta:PT RajaGrafindo Persada.

Patar, A., Darminto, dan M. Saifi. 2014. Faktor Internal dan Eksternal yang Mempengaruhi Pergerakan Harga Saham Studi pada Saham-saham Indeks LQ45 Periode 2009-2013. Jurnal Administrasi Bisnis 11(1): 1-9.

Pertiwi, NK.L.D. 2017. Pengaruh Kinerja Keuangan Terhadap Harga Saham Pada Perusahaan Perbankan Yang Listing Di Bursa Efek Indonesia (BEI). Skripsi tidak dipublikasikan.

Satria, I., dan Hatta, I.H. 2015. Pengaruh Kinerja Keuangan Terhadap Harga Saham 10 Bank Terkemuka di Indonesia. Jurnal Akuntansi, 19 (2):179-191.

Setiawati, N.M.S. 2015. Pengaruh Kinerja Keuangan Terhadap Harga Saham Pada Perusahaan Perbankan Yang Terdaftar Di Bursa Efek Indonesia. Skripsi tidak dipublikasikan.

Sujarweni, V.W. 2017. Analisis Laporan Keuangan. Yogyakarta:Pustaka Baru Press.

Sunariyah. 2011. Pengantar Pengetahuan Pasar Modal .Yogyakarta: STIE YKPN.

Ulfa, M. 2014. Pengaruh Kinerja Keuangan Terhadap Harga Saham Bank Umum Milik Pemerintah di BEI. Jurnal Riset dan Ilmu Manajemen. 3 (11):1-18

UU Republik Indonesia. 1998. Undang-Undang Republik Indonesia nomor: 10 tahun 1998 tentang Perbankan. Jakarta: Undang-Undang Republik Indonesia.

Wiagustini, N.L.P. 2013. Manajemen Keuangan. Denpasar:Udayana University Press. 